\title{
Photosynthesis, respiration, and carbon turnover in sinking marine snow from surface waters of Southern California Bight: implications for the carbon cycle in the ocean
}

\author{
Helle Ploug ${ }^{1, *}$, Hans-Peter Grossart ${ }^{2, * *}$, Farooq Azam $^{2}$, Bo Barker Jørgensen ${ }^{1}$ \\ ${ }^{1}$ Max-Planck Institute for Marine Microbiology, Celsiusstr. 1, D-28359 Bremen, Germany \\ ${ }^{2}$ Scripps Institution of Oceanography, University of California, San Diego, La Jolla, California 92093, USA
}

\begin{abstract}
Photosynthesis and respiration were measured in 1 to $6 \mathrm{~mm}$ large aggregates (marine snow) collected in the Southern Californian Bight, USA. The aggregates were freely sinking in a vertical flow system. with an upward flow velocity which opposed the sinking velocity of individual aggregates during the measurements. The aggregates were net heterotrophic communities at light intensities $<152 \pm 64 \mu \mathrm{E} \mathrm{m}^{-2} \mathrm{~s}^{-1}$, and respiration comprised $75 \pm 21 \%$ of gross photosynthesis at saturating light intensities $>500 \mu \mathrm{E} \mathrm{m}^{-2} \mathrm{~s}^{-1}$. Bacterial densities on aggregates were $>2000$-fold higher than in the surrounding water. Cytophaga was highly abundant in the aggregate-associated bacterial community as identified by in situ hybridization techniques. Both the respiration rate per aggregate volume and the bacterial densities decreased with increasing aggregate size. The respiration rates normalized to the number of bacteria in single aggregates were 7.4 to $70 \mathrm{fmol} \mathrm{C}$ cell ${ }^{-1} \mathrm{~d}^{-1}$ The aggregate community respired 433 to $984 \mathrm{ng} \mathrm{C} \mathrm{d}^{-1}$ per aggregate in darkness, which yielded a turnover time of 8 to $9 \mathrm{~d}$ for the total organic carbon in aggregates. Thus, marine snow is not only a vehicle for vertical flux of organic matter; the aggregates are also hotspots of microbial respiration which cause a fast and efficient respiratory turnover of particulate organic carbon in the sea
\end{abstract}

KEY WORDS: Oxygen microelectrodes - Marine bacteria - Organic matter Hydrolysis - Cytophaga

\section{INTRODUCTION}

Macroscopic organic aggregates larger than $0.5 \mathrm{~mm}$ (marine snow) comprise a significant fraction of the mass flux of organic matter in the ocean (Shanks \& Trent 1980, Fowler \& Knauer 1986, Alldredge \& Silver 1988, Turley \& Mackie 1994). Marine snow is, therefore, important for the export of particulate organic carbon (POC) from the euphotic zone to the sediments or the deep ocean, i.e. for the ocean's 'biological carbon pump'. The flux of POC, however, decreases with increasing depth in the ocean (Knauer et al. 1979,

Present addresses:

- Marine Biological Laboratory, University of Copenhagen, Strandpromenaden 5, DK-3000 Helsingor, Denmark.

E-mail: helle_ploug@inet.zitech.dk

- Institute for Chemistry and Biology of the Marine Environment (ICBM), University of Oldenburg, PO Box 2503,

D-26111 Oldenburg, Germany
Knauer \& Martin 1981, Lee \& Wakeham 1988). Marine snow is a microhabitat highly enriched in phytoplankton, bacteria, flagellates and detritus compared to the surrounding water, and the attached microorganisms have been considered to control the remineralization of the sinking fraction of POC (Caron et al. 1982, Alldredge \& Silver 1988, Turley \& Mackie 1994). However, on marine snow, the carbon demand of attached bacteria, estimated by their production rates, is often so small that months to years would be required for the bacteria to consume all the organic carbon of the aggregate after it is exported from the euphotic zone (Karl et al. 1988, Simon et al. 1990, Smith et al. 1992). This discrepancy between the observed rapid decrease in POC and the dense populations of microorganisms on marine snow and the surprisingly low bacterial carbon demand of the attached bacteria has been stated as a 'particle decomposition paradox' in the ocean (Karl et al. 1988). 
Particle dissolution through enzymatic hydrolysis of the aggregate carbon and particulate amino acids by the attached bacteria has been shown to be a significant and fast degradation process during sinking. The enzymatic hydrolysis and uptake of the hydrolysate by the aggregate-associated bacteria were not closely coupled since amino acids were released into the surrounding water (Smith et al. 1992). As a result, a large fraction of carbon and nutrients is processed and assimilated by free-living bacteria in the surrounding water rather than by the microbial community attached to the particles (Cho \& Azam 1988, Smith et al. 1992, Grossart \& Simon 1998).

Strong gradients in oxygen concentration and $\mathrm{pH}$ in marine snow, and even anoxic conditions in large fecal pellets, have been demonstrated by the use of microelectrodes (Alldredge \& Cohen 1987). It has been hypothesized that diffusion limitation and the chemical microenvironment, e.g. anoxia and low pH, of sinking aggregates may limit bacterial growth of the attached community (Azam et al. 1993) as the growth rates of bacteria on marine snow seldom are higher than 1 division $\mathrm{d}^{-1}$ (Alldredge \& Gotschalk 1990, Simon et al. 1990).

The respiration rate of the attached community of microorganisms and the actual carbon turnover in sinking aggregates have remained unknown and the question as to why attached bacteria apparently do not utilize the aggregate carbon and nutrients more efficiently remains open. In the present study we have directly measured respiration rates in sinking marine snow to test if the turnover of particulate organic matter by the attached microorganisms is indeed as slow as estimated by the production measurements. Community photosynthesis, respiration, enzymatic hydrolysis, enumeration and identification of bacteria on marine snow were evaluated in relation to POC and particulate organic nitrogen (PON) content. This allowed us to determine the turnover time of the POC in the aggregates in relation to their estimated sedimentation time.

\section{MATERIALS AND METHODS}

Sampling of marine snow. During 6 to 28 June 1997 individual aggregates were collected by SCUBA in acid-cleaned glass bottles (120 ml, Wheaton, USA) at 0 to $15 \mathrm{~m}$ depth ca $2 \mathrm{~km}$ northeast of Two Harbors, Catalina Island, in the Southern Californian Bight, USA. The collection was done in the morning (08:00 to 10:00 $\mathrm{h}$ ) and the aggregates remained in the glass bottles in a cooling box for $<1 \mathrm{~h}$ until further analysis in the lab. The incident light intensity at the sea surface measured as downward irradiance varied from $200 \mu \mathrm{E}$ $\mathrm{m}^{-2} \mathrm{~s}^{-1}(08: 00 \mathrm{~h})$ to $2000 \mu \mathrm{E} \mathrm{m} \mathrm{m}^{-2} \mathrm{~s}^{-1}(12: 00 \mathrm{~h})$. The depth at which the scalar irradiance was attenuated to $10 \%$ of the downward irradiance at the sea surface was $27 \mathrm{~m}$ at 08:00 h.

Microelectrode measurements. Oxygen gradients were measured in sinking individual aggregates kept in suspension by an upward directed flow, which balanced their sinking rates as earlier described (Ploug \& Jørgensen 1999). Ten liters of surface seawater was collected, filtered ( $\mathrm{GF} / \mathrm{C}$ ) and used in the flow system. All measurements were done at in situ temperature $\left(17^{\circ} \mathrm{C}\right)$, using a Clark-type microelectrode (Revsbech 1989) with a $4 \mu \mathrm{m}$ wide sensing tip, a $90 \%$ response time of $0.2 \mathrm{~s}$, and a stirring sensitivity of $<0.3 \%$. The microelectrode was calibrated in air-saturated and in $\mathrm{N}_{2}$-flushed seawater. The electrode signal was measured by a picoammeter connected to a computerbased data acquisition system with a data collection frequency of $510 \mathrm{~Hz}$ (LabVIEW 2, National Instruments). The position of the aggregate surface was determined by slowly advancing the microelectrode towards the aggregate until it visibly touched the upper surface as observed under a dissecting microscope. The gradients were measured after steady-state had been reached at the different light conditions or in darkness. The light source was a $150 \mathrm{~W}$ halogen fiberoptic lamp equipped with an infra-red cut-off filter (Schott, Kl 1500). The light intensity was controlled by the use of neutral density filters (Oriel) and measured inside the chamber with an underwater scalar irradiance sensor (Biospherical Instruments QLS 100). The dimensions of the aggregates were measured under the dissecting microscope while they were in the flow system. Immediately after the microelectrode measurements, the aggregates were fixed in $4 \%$ paraformaldehyde solution and stored at $4^{\circ} \mathrm{C}$ for less than 2 wk until enumeration of attached bacteria.

Analysis of $\mathbf{O}_{2}$ gradients. The measured oxygen gradients in the boundary layer were used to determine the oxygen fluxes and, thereby, the net photosynthesis and respiration rates in the aggregates (Ploug et al. 1997). The diffusion coefficient for oxygen is $1.88 \times$ $10^{-5} \mathrm{~cm}^{2} \mathrm{~s}^{-1}\left(17^{\circ} \mathrm{C}\right)$ (Broecker \& Peng 1974). The diffusion calculations were made for an ellipsoid with 3 half-axes $a, b$, and $c$, where $a<b<c$. The surface area of an ellipsoid is (Maas 1994):

$A=2 \pi a C\left[\frac{c}{a}+\frac{b}{a} \sqrt{1-\left(\frac{c}{a}\right)^{2}} E(\varphi, \kappa)+\frac{b}{a} \frac{c}{a} \frac{1}{\sqrt{1-(c / a)^{2}}} F(\varphi, \kappa)\right]$

where

$$
\varphi=\arcsin \sqrt{1-\left(\frac{c}{a}\right)^{2}} ; \quad \kappa^{2}=\frac{1-(c / b)^{2}}{1-(c / a)^{2}}
$$

and $F(\phi, \kappa)$, and $E(\phi, \kappa)$ denote the (incomplete) elliptic integrals of the first and second kind, respectively, as 
tabulated in Spiegel (1968). The volume of an ellipsoid is $4 / 3 \pi a b c$ (Spiegel 1968).

Gross photosynthesis was determined from the outward directed net fluxes of oxygen at saturating light intensity plus the inwards directed flux in darkness, i.e. assuming respiration during light to be equal to dark respiration. Photosynthesis and respiration rates were converted to carbon equivalents by using a conversion factor of $1.2 \mathrm{~mol} \mathrm{O}_{2}$ to $1 \mathrm{~mol}$ carbon.

The data for size-specific respiration rates and bacterial densities were fitted by an allometric function. The curve fitting was done with a non-linear regression Levenberg-Marquardt algorithm (Origon 3.0, MicroCal Software Inc.).

Enumeration of bacteria. Bacteria on marine snow and in the surrounding water were counted after DAPI staining by epifluorescence microscopy (Porter \& Feig 1980). Two ml subsamples of surrounding water were filtered directly onto $0.2 \mu \mathrm{m}$ nuclepore membranes. To remove bacteria from marine snow, single or pooled aggregates were treated with ultrasound in $2 \mathrm{mM} \mathrm{Na-}$ pyrophosphate (Velji \& Albright 1986) prior to filtration.

Bacteria and Cytophaga. Percentages of Bacteria and members of the Cytophaga-flexibacterium-bacteroides group (Cytophaga) were examined by in situ hybridization with $16 \mathrm{~S}$ rRNA-targeted fluorescent oligonucleotide probes according to Weiss et al. (1996) Twenty $\mu l$ aliquots of sonicated aggregates were pipetted onto gelatin-coated Teflon microslides (P. Marienfeld KG, Bad Mergentheim, Germany) and dried at $46^{\circ} \mathrm{C}$. The samples were then fixed in $40 \mu \mathrm{l}$ of fresh paraformaldehyde $(4 \%)$ for $4 \mathrm{~h}$ at $4^{\circ} \mathrm{C}$. Oligonucleotide probes specific for Bacteria (EUB, Amann et al. 1990) and Cytophaga of the CFB group (Amann et al. 1995) were used.

Hydrolytic enzyme activities. Hydrolytic enzyme activities of free-living and attached bacteria were measured with fluorogenic analogs of natural substrates (Hoppe 1993): L-leucine-methyl coumarinylamide (MCA, aminopeptidase), methyl umbelliferyl- $\alpha$ and $\beta$-D-glucoside (MUF, $\alpha$ - and $\beta$-glucosidase Hydrolysis by free-living bacteria was measured by incubation of $5 \mathrm{ml}$ subsamples with $50 \mu \mathrm{M}$ fluorogenic substrates for $1 \mathrm{~h}$ at in situ temperature in the dark. Hydrolysis by aggregate-associated bacteria was measured on single aggregates in $5 \mathrm{ml}$ seawater with 250 to $500 \mu \mathrm{M}$ substrates. These concentrations assured maximum hydrolysis rates as determined by saturation kinetics. A control, heat-killed at $80^{\circ} \mathrm{C}$ for $20 \mathrm{~min}$, was made for both free-living and aggregate-associated bacteria. Fluorescence was measured at 380/365 nm excitation and 440/455 nm emission for MUF / MCA substrates in a fluorometer (Hoefer TKO-100). The activity of aggregate-associated bacteria was calcu- lated as the total activity minus that of free-living bacteria.

Dry weight and CHN analysis. For measurements of the dry weight and the CHN elemental composition, 10 individual aggregates were pooled and filtered onto precombusted and preweighed $\left(W_{0}\right)$ glass microfiber filters ( $1 \mu \mathrm{m}$ pore-size, Schleicher \& Schüll, Germany). The filters were dried at $110^{\circ} \mathrm{C}$ for $1 \mathrm{~h}$ and weighed again $\left(W_{1}\right)$. The mean dry weight of 1 aggregate was determined as $\left(W_{1}-W_{0}\right) / 10$. Filters were then fumed overnight with $\mathrm{HCl}$ (20\% final conc.) to remove the inorganic carbon. The percentage of organic carbon and nitrogen was determined in a CHN analyzer (Perkin Elmer, USA). The amount of organic carbon or nitrogen per aggregate was calculated from the average dry weight and the average percentage of carbon or nitrogen.

Colonization/growth experiments. Individual aggregates were kept in the $120 \mathrm{ml}$ sampling bottles at in situ temperature in a $12: 12 \mathrm{~h}$ dark-light cycle for 1 to $3 \mathrm{~d}$; bacterial numbers were counted after DAPI staining (see above), and the number and percentage of Bacteria and Cytophaga were determined after in situ hybridization (see above).

\section{RESULTS}

\section{Characterization of aggregates}

The mean equivalent spherical diameter (ESD) of the aggregates was $2.90 \pm 1.28 \mathrm{~mm}$. The ratio of the longest to the shortest axis was $1.23 \pm 0.25$. Measurements of dry weight, POC and PON were made on 2 sampling dates (Table 1). The average dry weight of aggregates was $62.2 \pm 44.4$ and $91.1 \pm 32.9 \mu$ agg. $^{-1}$ on 27 and 28 June, respectively. The POC content was $3.87 \pm 1.08$ and $7.77 \pm 1.07 \mu \mathrm{g} \mathrm{C}$ agg. ${ }^{-1}$ on 27 and 28 June, respectively, and comprised 6.2 and $8.5 \%$ of the dry weight. The aggregates on 28 June were larger and had a higher $C: N$ ratio (16.9:1) than those on 27 June (12.2:1). The phytoplankton of the aggregates was mainly composed of diatoms and cyanobacteria (Synechococcus sp.). The aggregates had an apparently high content of exopolymers and indefinable

Table 1 Dry weight, POC content, and C: $N$ ratio in aggregates. Data show the mean $\pm S D$ values

\begin{tabular}{|lccc|}
\hline & $\begin{array}{c}\text { Dry weight } \\
\left(\mu \mathrm{g} \mathrm{C} \text { agg. }^{-1}\right)\end{array}$ & $\begin{array}{c}\text { POC } \\
\left(\mu \mathrm{C} \text { agg }^{-1}\right)\end{array}$ & $\begin{array}{c}\mathrm{C}: \mathrm{N} \\
(\mathrm{w}: \mathrm{w})\end{array}$ \\
\hline 27 June & $62.2 \pm 44.4$ & $3.87 \pm 1.08$ & 12.2 \\
28 June & $91.1 \pm 32.9$ & $7.77 \pm 1.07$ & 16.9 \\
\hline
\end{tabular}




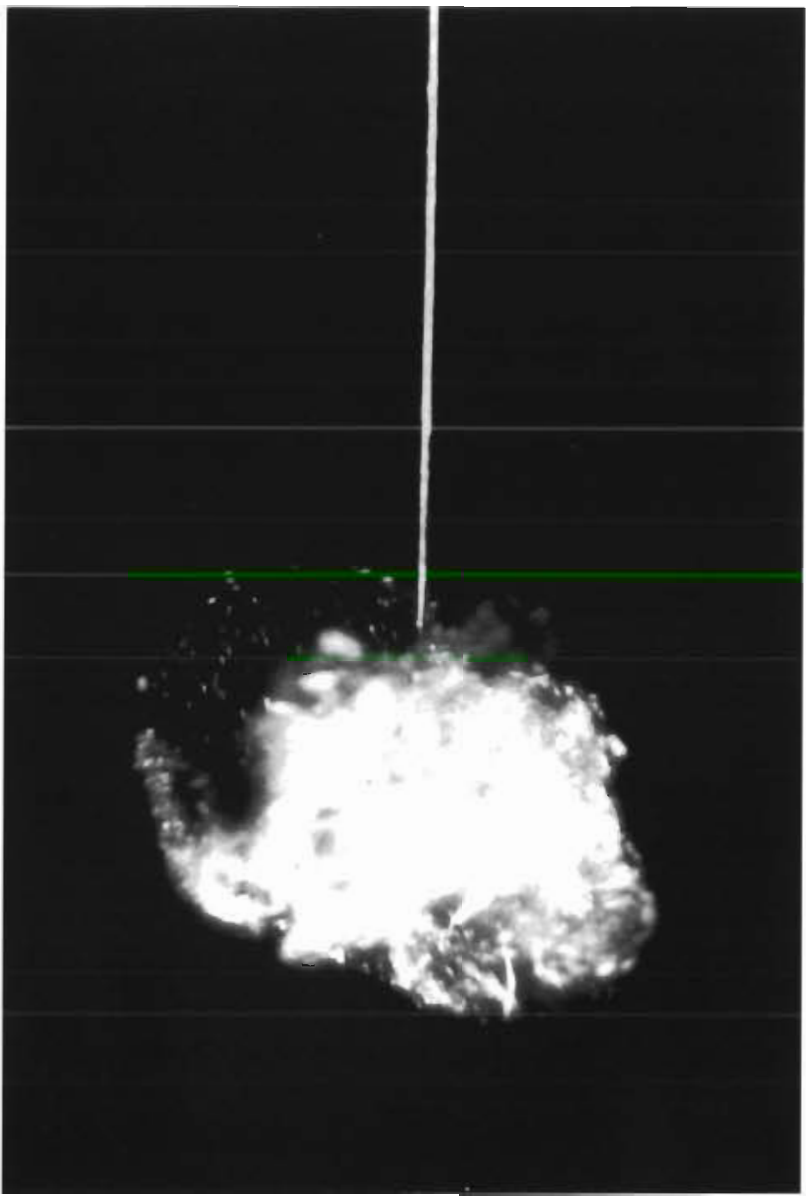

Fig. 1. A $3 \mathrm{~mm}$ large aggregate photographed through a dissection microscope is freely suspended by an upward flow velocity which balances its sinking velocity. An oxygen microelectrode is inserted from above

material. An example of the aggregates in the experimental setup is shown in Fig. 1.

\section{Photosynthesis and respiration}

The oxygen gradients in the diffusive boundary layer (DBL) at the aggregate-water interface and $0.5 \mathrm{~mm}$ below the upper surface of the aggregates were measured in darkness, at the compensating light intensity, and at the light intensity at which photosynthesis was saturated. The gradients were small but significant as shown by the small standard deviations of the mean concentrations at the different light conditions. At the aggregate surface, the $\mathrm{O}_{2}$ concentration ranged from $96 \%$ in darkness to $102 \%$ of air saturation measured at $550 \mu \mathrm{E} \mathrm{m}^{-2} \mathrm{~s}^{-1}$ (Fig. 2). At the compensating light intensity all the $\mathrm{O}_{2}$ produced by photosynthesis is consumed by the heterotrophic processes within the community, and there is no net exchange of oxy- gen between the aggregate and the surrounding water. The compensating light intensity was $220 \mu \mathrm{E}$ $\mathrm{m}^{-2} \mathrm{~s}^{-1}$ in the aggregate shown in Fig. 2. The aggregates were very sticky on the electrode and the distribution of $\mathrm{O}_{2}$ could, therefore, not be determined through whole aggregates without pushing the aggregates with the electrode during the measurements. Oxygen concentrations inside aggregates in the dark were always $>90 \%$ of air saturation (data not shown). The net oxygen exchange between the aggregate community and the surrounding water occurs through the DBL. The gradients through the DBL at the aggregate-water interface are, therefore, determined by the net photosynthesis and respiration rates of the whole aggregate community. The net oxygen fluxes of sinking aggregates have been shown not to differ significantly between the upstream and downstream side (Ploug et al. 1997, Ploug \& Jørgensen 1999). The gradients in the DBL of only the upper (i.e. downstream) side were, therefore, used to determine net photosynthesis and respiration rates of the whole aggregate community.

Net photosynthesis ranged from 0 to $340 \mathrm{ng} \mathrm{C} \mathrm{agg.}{ }^{-1}$ $\mathrm{d}^{-1}$ at saturating light intensity, and the dark respiration ranged from 80 to $3600 \mathrm{ng} \mathrm{C}$ agg. ${ }^{-1} \mathrm{~d}^{-1}$ in aggregates of different sizes (Fig. 3). The gross photosynthesis calculated as net photosynthesis + dark respiration ranged from 110 to $3600 \mathrm{ng} \mathrm{C}$ agg. ${ }^{-1} \mathrm{~d}^{-1}$. The average compensating light intensity was $152 \pm 61 \mu \mathrm{E} \mathrm{m}^{-2} \mathrm{~s}^{-1}$ and dark respiration comprised on average $75 \pm 21 \%$ of gross photosynthesis at saturating light intensities of $>500 \mu \mathrm{E} \mathrm{m}^{-2} \mathrm{~s}^{-1}$. In some aggregates the dark respiration was equal to the gross photosynthesis also at saturating light intensities, meaning that net photosynthesis was zero. The autotrophic and heterotrophic

\section{$\mathrm{O}_{2}$ (in \% of air saturation)}

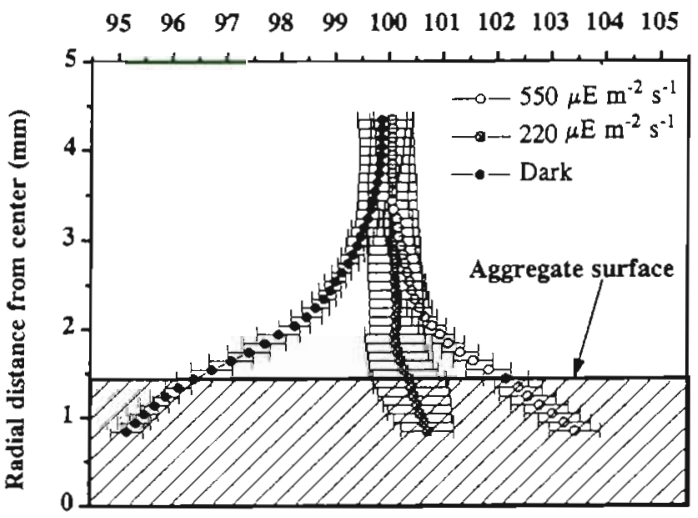

Fig. 2. Oxygen gradients in the diffusive boundary layer (DBL) of the aggregate shown in Fig. 1 measured in darkness and at 2 different light intensities. Data points represent the mean $\pm \mathrm{SD}$ of 3 gradients Note the expanded $\mathrm{O}_{2}$ scale 


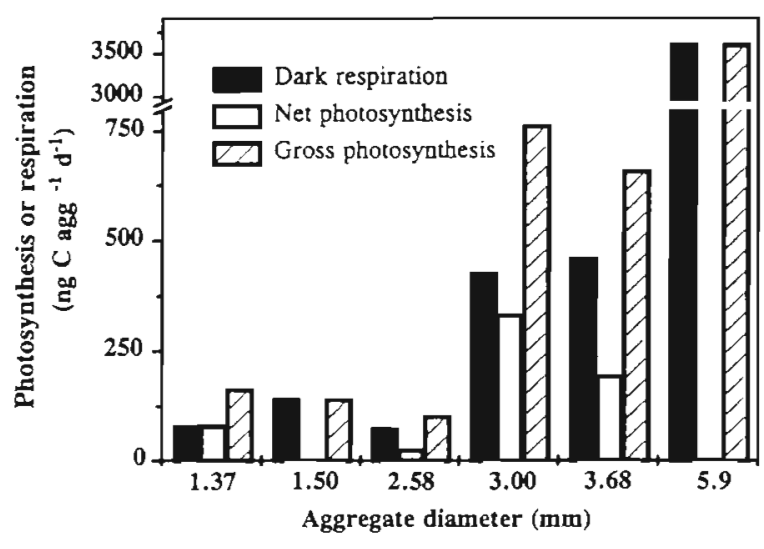

Fig. 3. Gross photosynthesis, net photosynthesis, and respiration rates in individual aggregates as determined from the oxygen fluxes in dark and at saturating light intensities (see text). Absence of photosynthesis columns means zero rate. Each bar represents the mean of 3 gradient measurements

processes were therefore tightly coupled through carbon and oxygen being recycled within the aggregate. Marine snow of the surface waters were, thus, net heterophic communities not only in the dark, but also when the light intensity was below $152 \pm 61 \mu \mathrm{E} \mathrm{m}^{-2} \mathrm{~s}^{-1}$.

\section{Community respiration rates and bacterial numbers in aggregates}

The respiration rate per aggregate volume decreased with increasing aggregate size (Fig. 4A), although the total respiration rate increased with increasing aggregate size (Fig. 3). Volume-specific respiration rates could be described by: $0.61 \times \mathrm{ESD}^{-1.50} \mathrm{nmol}$ $\mathrm{O}_{2} \mathrm{~mm}^{-3} \mathrm{~h}^{-1}$, where ESD is in $\mathrm{mm} . \mathrm{R}^{2}$ was 0.61 .

The number of bacteria attached to the aggregates was on average $1.16 \times 10^{6} \mathrm{agg}^{-1}$, or ca 2000 -fold higher per aggregate volume than in the surrounding water. The number of bacteria per aggregate volume decreased nearly 2 orders of magnitude with increasing aggregate size according to bacterial density $=1.49$ $\times 10^{9} \times \mathrm{ESD}^{-2.69}$ bac. $\mathrm{ml}^{-1} ; \mathrm{R}^{2}=0.98$ (Fig. 4B). The bacterial densities decreased relatively more with increasing aggregate diameter than the volume-specific respiration rates. Community respiration rates per bacterial cell were lower in small aggregates than in large aggregates (Fig. 5A). The large aggregates harbored less bacteria per aggregate volume, and community respiration rates per bacterial cell decreased with increasing bacterial density as described by: $10.4 \times$ (bac. $\mathrm{ml}^{-1}$ ) $^{-054}$ fmol $\mathrm{O}_{2}$ bac. ${ }^{-1} \mathrm{~d}^{-1} ; \mathrm{R}^{2}=0.66$ (Fig. 5B).

The high respiration rates per bacterial cell indicate that aggregate-associated bacteria were catabolically highly active. The bacterial number in aggregates
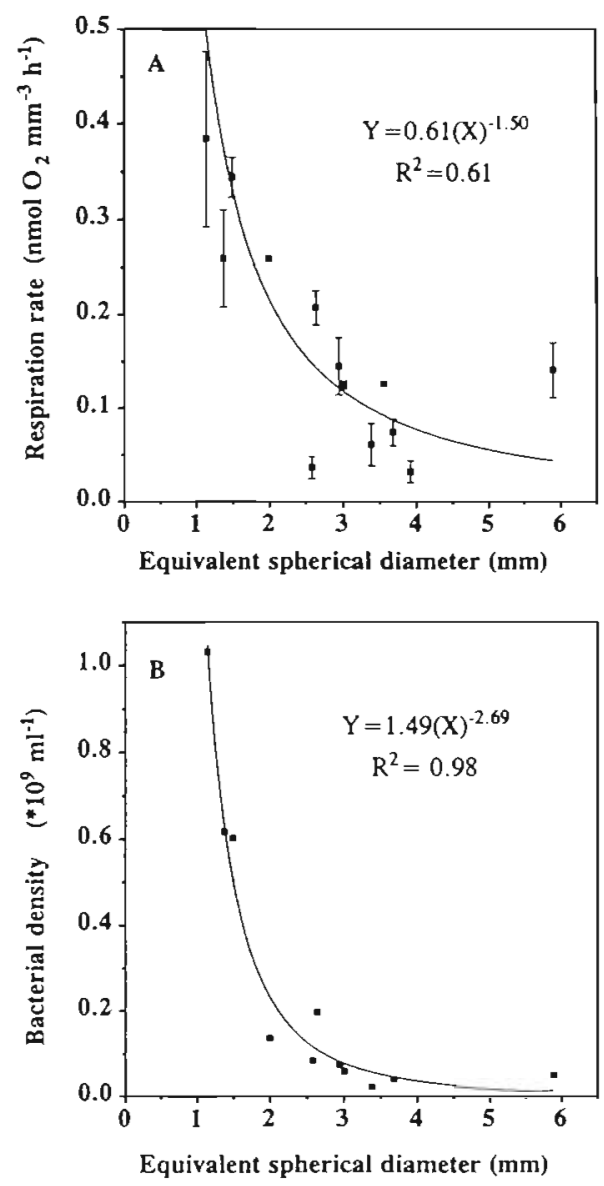

Fig. 4. (A) Respiration rates in the dark and (B) bacterial densities normalized to aggregate volume for different aggregate sizes. Each data point represents the mean \pm SD of the mean for 3 series of measurements

fixed immediately after collection was 2.4 -fold lower than of the number fixed after the microelectrode measurements or after 1 to $3 \mathrm{~d}$ of incubation in the glass sampling bottles without stirring (Table 2). A high percentage of all aggregate-attached bacteria belonged to the Bacteria domain (92 to $99.2 \%$ ), of which 8.9 to $73.7 \%$ belonged to Cytophaga. The total number of bacteria and the percentage of Bacteria as well as of the Cytophaga group increased with time after collection. The high detection level by the $16 \mathrm{~S}$ rRNA oligonucleotide probes as well as the increase in total number with time indicates that bacteria on marine snow were highly active. The increase in bacterial numbers with time, however, can partly be due to cellular growth of the aggregate-attached bacteria as well as increased colonization by bacteria from the surrounding water.

Enzymatic hydrolysis rates. The potential hydrolysis rates by $\alpha$ - and $\beta$-glucosidase, aminopeptidase, phosphatase, and chitinase were measured at high sub- 
Table 2. Bacteria number per aggregate and community composition versus age. Data show the mean $\pm \mathrm{SD}$ values. Data range is shown in parentheses

\begin{tabular}{|c|c|c|c|}
\hline Age at fixation & $\begin{array}{l}\text { DAPl-stained } \\
\text { bacteria }\left(\times 10^{6}\right)\end{array}$ & $\begin{array}{l}\text { Bacteria } \\
(\% \text { of DAPI })\end{array}$ & $\begin{array}{l}\text { Cytophaga } \\
(\% \text { of Bacteria })\end{array}$ \\
\hline Freshly collected aggregates $(\mathrm{n}=27$; each sample $=10$ pooled agg. $)$ & $\begin{array}{l}0.48 \pm 0.16 \\
(0.13-0.79)\end{array}$ & $\begin{array}{c}96.3 \\
(92.0-98.5)\end{array}$ & $\begin{array}{c}22.9 \\
(8.90-62.7)\end{array}$ \\
\hline Fixed after $\mathrm{O}_{2}$ measurements within the day of collection $(n=15)$ & $\begin{array}{l}1.16 \pm 1.13 \\
(0.37-5.7)\end{array}$ & $\begin{array}{c}97.0 \\
(95.7-99.0)\end{array}$ & $\begin{array}{c}28.4 \\
(13.7-71.9)\end{array}$ \\
\hline Fixed after $1 \mathrm{~d}$ incubation without stirring $(n=7)$ & $\begin{array}{l}1.17 \pm 0.27 \\
(0.77-1.36)\end{array}$ & $\begin{array}{c}98.2 \\
(94.5-99.2)\end{array}$ & $\begin{array}{l}32.2 \\
(13.0-50.6)\end{array}$ \\
\hline Fixed after $3 \mathrm{~d}$ incubation without stirring $(n=4)$ & $\begin{array}{l}1.00 \pm 0.49 \\
(0.67-1.73)\end{array}$ & $\begin{array}{c}96.7 \\
(95.3-98.5)\end{array}$ & $\begin{array}{c}33.22 \\
(17.3-73.7)\end{array}$ \\
\hline
\end{tabular}

strate concentrations of 250 to $500 \mu \mathrm{M}$ in the surrounding water. The potential hydrolysis rates are shown in Table 3 . The hydrolysis rates were highly variable. Potential activities of $\alpha$ - and $\beta$-glucosidase were unusually high 5.23 and $2.43 \mathrm{fmol} \mathrm{bac}^{-1} \mathrm{~h}^{-1}$. Amino-
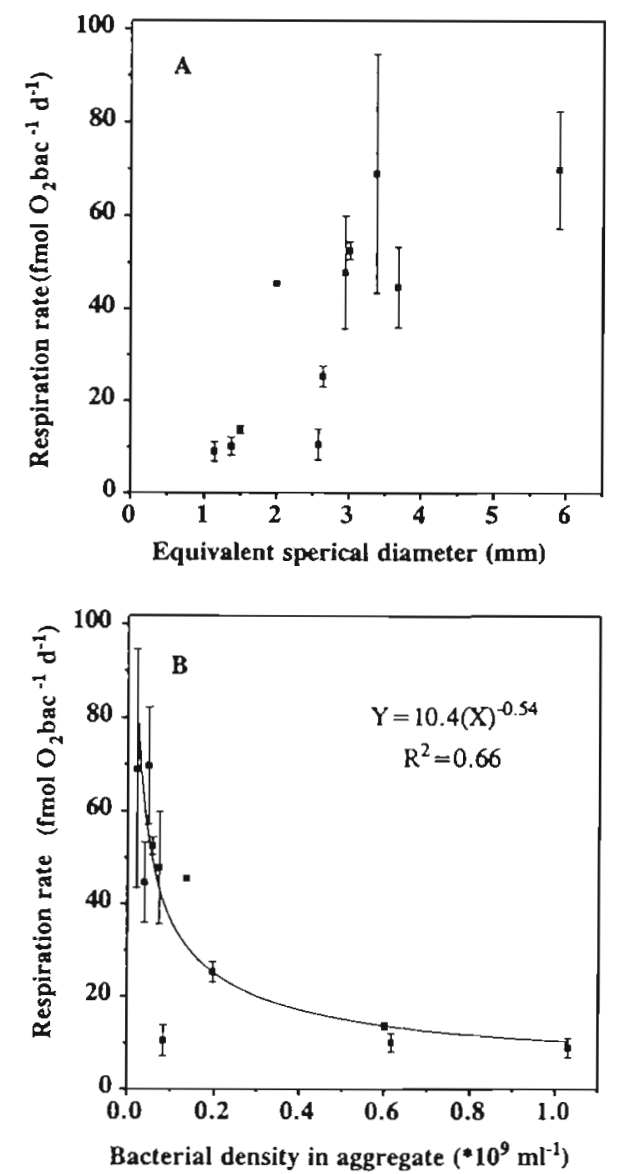

Fig. 5. (A) Respiration rates per bacterial cell relative to the aggregate size, and $(B)$ the bacterial density. Each data point represents the mean \pm SD for 3 series of measurements
Table 3. Potential hydrolysis rates in aggregates. Data show the mean $\pm \mathrm{SD}$ values. Data range is shown in parentheses

\begin{tabular}{|ll|}
\hline Enzyme activity & Rate $\left(\mathrm{fmol} \mathrm{bac}{ }^{-1} \mathrm{~h}^{-1}\right)$ \\
\hline $21-22$ Jun & \\
$\alpha$-Glucosidase & $5.23 \pm 5.0(0.83-13.5)$ \\
$\beta$-Glucosidase & $2.43 \pm 1.44(0.75-4.2)$ \\
Phosphatase & $1.22 \pm 1.37(0.04-3.20)$ \\
Chitinase & $2.43 \pm 1.44(2.37-6.93)$ \\
Aminopeptidase & $21.1 \pm 7.44(12.9-36.0)$ \\
27-28 Jun & $187 \pm 120(69.5-368)$ \\
Aminopeptidase & \\
\hline
\end{tabular}

peptidase activity was $21.1 \mathrm{fmol} \mathrm{bac.}^{-1} \mathrm{~h}^{-1}$ on 21-22 June and increased to $187 \mathrm{fmol} \mathrm{bac}^{-1} \mathrm{~h}^{-1}$ on $27-28$ June.

\section{Carbon turnover by microbial respiration on marine snow}

The mean respiration rates were $0.433 \pm 0.215$ and $0.984 \pm 1.78 \mu \mathrm{g} \mathrm{C} \mathrm{agg.}^{-1} \mathrm{~d}^{-1}$, respectively, on 27 and 28 June. The respiration rates were calculated as the mean of aggregates of random sizes, which explains the high standard deviation of the mean. The carbon turnover time due to respiration alone estimated from the ratio of the POC content and the mean respiration rates was 7.9 and $8.9 \mathrm{~d}$, respectively, on 27 and 28 June. Settling velocities of the aggregates were very variable (10 to $\left.65 \mathrm{~m} \mathrm{~d}^{-1}\right)$. The average settling velocity was relatively low $31 \pm 18 \mathrm{~m} \mathrm{~d}^{-1}$, presumably due to their high mucus content. As the water column was approximately $200 \mathrm{~m}$ deep, the average minimum residence time was $7 \mathrm{~d}$. Assuming that the respiration rate was independent of time and quality of the carbon pool, $80 \%$ of the POC content could potentially be respired before the aggregates reached the sea floor. 
Carbon to support the respiration in aggregates may, however, also be scavenged from the surrounding water by sinking aggregates in the ocean.

\section{DISCUSSION}

\section{Photosynthesis and respiration}

Photosynthesis, bacterial production, and enzymatic hydrolysis have been studied intensively on marine snow (Alldredge et al. 1986, Alldredge \& Gotschalk 1990, Simon et al. 1990, Smith et al. 1992, Turley \& Mackie 1994); however respiration rates have not previously been quantified. Photosynthesis has been measured by ${ }^{14} \mathrm{C}$-techniques in disrupted marine snow. The rates were found to vary widely between 8.1 and $2170 \mathrm{ng} C$ agg. $^{-1} \mathrm{~d}^{-1}$ (Alldredge \& Gotschalk 1990, Simon et al. 1990).

In the present study, net and gross photosynthesis were calculated from the $\mathrm{O}_{2}$ fluxes to or from intact sinking aggregates during darkness and in light. The respiration in light cannot be detected by the steadystate fluxes; however it can be detected from the dynamic changes of oxygen concentrations during shifts between light and dark (Revsbech et al. 1981). Respiration during photosynthesis has been shown to be up to 5-fold higher than dark respiration in diatom aggregates, presumably due to photorespiration in the algae and/or excretion of easily degradable carbohydrates which may stimulate bacterial respiration (Ploug \& Jorgensen 1999). The gross photosynthesis may, therefore, be underestimated, as the respiration in light probably was higher than the dark respiration.

Net photosynthesis at light saturation ranged from 0 to $340 \mathrm{ng} \mathrm{C} \mathrm{agg}^{-1} \mathrm{~d}^{-1}$. Gross photosynthesis was much higher and ranged from 110 to $3600 \mathrm{ng} \mathrm{C}$ agg. ${ }^{-1} \mathrm{~d}^{-1}$, as most of the oxygen produced during photosynthesis was respired within the aggregates. The aggregates were net heterotrophic at light intensities up to $152 \pm$ $64 \mu \mathrm{E} \mathrm{m} \mathrm{m}^{-2} \mathrm{~s}^{-1}$. Compensating light intensities in colonies and aggregates of the planktonic microalgae, Phaeocystis sp. have previously been found to be much lower $\left(7\right.$ to $10 \mu \mathrm{E} \mathrm{m}^{-2} \mathrm{~s}^{-1}$ ) in early stages during spring blooms in the North Sea and in the Barents Sea, and to increase at later stages of blooms $\left(80 \mu \mathrm{E} \mathrm{m}^{-2} \mathrm{~s}^{-1}\right)$, presumably due to increased bacterial colonization during the bloom. Dark respiration in such colonies and aggregates only comprised $12 \%$ of the gross photosynthesis measured from the steady-state fluxes at the early stages of the blooms (Ploug et al, in press). In the present study, the heterotrophic processes were much more important in the aggregate communities, as reflected in the relatively high light intensity at which photosynthesis could balance respiration within the community and the high dark respiration which comprised $75 \pm 21 \%$ of gross photosynthesis at light saturation.

\section{Dark respiration and oxygen microenvironments}

Steep gradients of oxygen and $\mathrm{pH}$ have previously been demonstrated in marine aggregates and fecal pellets placed in a small cone made of a plankton net (Alldredge \& Cohen 1987). In a recent study it was shown that sinking of aggregates greatly facilitates diffusion to the aggregates and results in 9-fold higher $\mathrm{O}_{2}$ concentration inside the aggregates as compared to aggregates sitting on a solid surface (Ploug \& Jørgensen 1999). The flow past the sinking aggregates is therefore important for its chemical microenvironment and, thus, for the growth conditions of the microbial community. Measured oxygen concentrations in darkness inside the aggregates of the present study were $\geq 90 \%$ of air saturation (225 $\mu \mathrm{M})$, at which the organisms cannot be diffusion limited by oxygen since the half-saturation constant, $K_{\mathrm{S}}$, for oxygen respiration is on the order of $1 \mu \mathrm{M}$ in heterotrophic microorganisms (Focht \& Verstraete 1977). If the aggregates had occurred in an oxygen minimum zone with a bulk water concentration of $10 \%$ of air saturation they may have been anoxic

Oxygen gradients are proportional to the community respiration rates in the aggregates when $K_{\mathrm{S}}$ is much lower than the oxygen concentration inside the aggregates (Ploug et al. 1997). Anoxia inside the aggregates of the present study with air-saturated water would, therefore, have required $\geq 10$-fold higher cell-specific respiration rates, or 10 -fold higher community densities. The bacterial numbers in those aggregates which we analyzed with microelectrodes ranged between $0.37 \times 10^{6}$ and $5.7 \times 10^{6}$. Other studies have also shown that bacteria numbers in aggregates larger than $3 \mathrm{~mm}$ usually range between $0.41 \times 10^{6}$ and $1.7 \times 10^{6}$ in the Southern California Bight (Alldredge et al. 1986, Simon et al. 1990). Such bacterial densities with similar respiration rates as estimated in the present study would be 10 -fold too low to create anoxic conditions inside the aggregates. Higher bacterial numbers have been observed in aggregates from the NE Atlantic, but bacterial numbers in the range of $10^{7}$ to $10^{8}$ in aggregates are rare unless the aggregates are very large (Alldredge et al. 1986, Alldredge \& Gotschalk 1990). This higher limit of bacterial densities in aggregates may be determined by diffusion limitation of bacterial growth, available surface area, and probably grazing.

Flagellates have been shown to occur in high numbers on aggregates (Caron et al. 1982, Turley \& Mackie 1994). Their contribution to the community respiration 
is not known since it is difficult to measure separately. The average bacterial biomass on aggregates was $6.5 \mathrm{nmol} \mathrm{C}$, assuming a bacterial carbon content of $5 \mathrm{fmol} \mathrm{C}$ bac. $^{-1}$ (Simon et al. 1990). If $50 \%$ of the bacterial biomass was grazed per day by flagellates growing with a $50 \%$ growth efficiency and a respiratory quotient of $1.2 \mathrm{~mol} \mathrm{O}_{2}: \mathrm{mol} \mathrm{CO}_{2}$, the respiration rate by flagellates would be $[(0.5 \times 0.5 \times 6.5 \mathrm{nmol} \mathrm{CO} \times 1.2 \mathrm{~mol}$ $\left.\left.\mathrm{O}_{2} \mathrm{~mol} \mathrm{CO}_{2}{ }^{-1}\right) / 24 \mathrm{~h}\right]=0.081 \mathrm{nmol} \mathrm{O}_{2} \mathrm{~h}^{-1}$. The average community respiration rate of the measured aggregates was $2.7 \pm 4.2 \mathrm{nmol} \mathrm{O}_{2} \mathrm{~h}^{-1}$. The flageilates would, thus, contribute with $3 \%$ to the total community respiration.

\section{Dark respiration and carbon turnover}

The respiration rates normalized to bacterial number ranged from 1.5 - to 12 -fold the bacterial carbon biomass ( 7.4 to $58 \mathrm{fmol} \mathrm{C} \mathrm{bac}^{-1} \mathrm{~d}^{-1}$ ) assuming an average cell-specific carbon content of $5 \mathrm{fmol} \mathrm{C} \mathrm{bac.}{ }^{-1}$. The bacterial carbon content on marine snow, however, can vary 4 -fold (Simon et al. 1990). Respiration rates of free-living bacteria have been found in the same range in seawater samples highly enriched with glucose (Stoderegger \& Herndl 1998). The cell-specific bacterial production rate has also been shown to increase with increasing aggregate size and decreasing bacterial density in marine aggregates. At low densities, bacteria may compete less for available resources and therefore grow faster (Alldredge \& Gotschalk 1990). The high respiration rates measured in the present study suggest high growth rates or a low growth yield of the attached bacteria. The doubling time of bacteria attached to aggregates has been shown to range between 0.5 and $10 \mathrm{~d}$ (Alldredge \& Gottschalk 1990, Simon et al. 1990, Grossart \& Simon 1998). Unfortunately, we could not measure bacterial growth rates in this study.

Recent studies have shown that, whereas bacterial production is high and enzymatic hydrolysis is low in newly formed aggregates, bacterial production decreases and hydrolysis increases in aggregates after ca 3 d (Unanue et al. 1998). The potential hydrolysis rates and the $C: N$ ratio were high on the aggregates, which indicate that the aggregates were not newly formed (Table 3). Cytophaga were highly abundant on the aggregates, and the relative abundance of this group was shown to increase with time when aggregates were allowed to age in the lab (Table 2). Similar results were also found in a limnic study (Schweitzer 1998). Bacteria of the cytophaga group have previously been shown to dominate the bacterial community on marine snow, and they are known to be motile and can hydrolyze a variety of more refractory polymeric com- pounds, especially chitin and other polysaccharides (DeLong et al. 1993, Rath et al. 1998). The short turnover time of carbon by respiration may be a consequence of the cost of producing exoenzymes, which may lead to a low growth yield of the attached bacteria. Bacterial growth efficiencies have been shown to be 8 to $39 \%$ for free-living bacteria degrading high molecular weight DOC, and 16 to $66 \%$ when they degrade low molecular weight DOC (Amon \& Benner 1996).

A recent study of respiration rates and carbon turnover in lake snow in Lake Kinneret, Israel, showed respiration rates of 0.65 to $1.04 \mathrm{nmol} \mathrm{O} \mathrm{agg}^{-1} \mathrm{~h}^{-1}$ and a POC turnover time of 14 to $50 \mathrm{~d}$, as the respiration rates were lower and the POC content was higher in the aggregates of that study (Parparov et al. 1998). The POC content in the aggregates of the present study was in the same range but the dry weight was in the high range of that which has been previously found in marine aggregates (Alldredge 1979, 1998). The POC content of aggregates has been shown to comprise $8 \pm$ $1 \%$ of the dry weight during summer in the Gulf of California and 15 to $19 \%$ of the dry weight during winter in the Santa Barbara Channel (Alldredge 1979). The POC content as a percentage of dry weight is generally lower and the C:N ratio is higher in miscellaneous aggregates as compared to other types of aggregates of recognizable organic matter, e.g. diatoms, larvacean or fecal pellets (Alldredge 1998). The low POC content relative to the dry weight and the high $\mathrm{C}: \mathrm{N}$ ratio of the aggregates in the present study indicates that the aggregates were mainly dominated by inorganic matter and more refractory organic matter, presumably due to high hydrolysis and respiration rates.

\section{Implications for the vertical flux of carbon}

The respiration rates per aggregate volume decreased with increasing aggregate size (Fig. 4A). Also the dry weight, the POC and the PON content per aggregate volume showed a similar decrease with increasing aggregate size (Alldredge 1998). The common size-dependent distributions of dry weight, POC, and $\mathrm{PON}$ in aggregates may all be related to a general fractal geometry of the aggregates, because porosity increases with increasing aggregate size as the aggregates are formed by coagulation of smaller particles (Logan \& Wilkinson 1990, Mari \& Kiørboe 1996, Mari \& Burd 1998).

The size-dependent respiration rate as measured in the present study versus the size-dependent POC content of aggregates as determined by Alldredge (1998) is shown in Fig. 6A. The carbon turnover time as a function of aggregate size was calculated from the POC content 

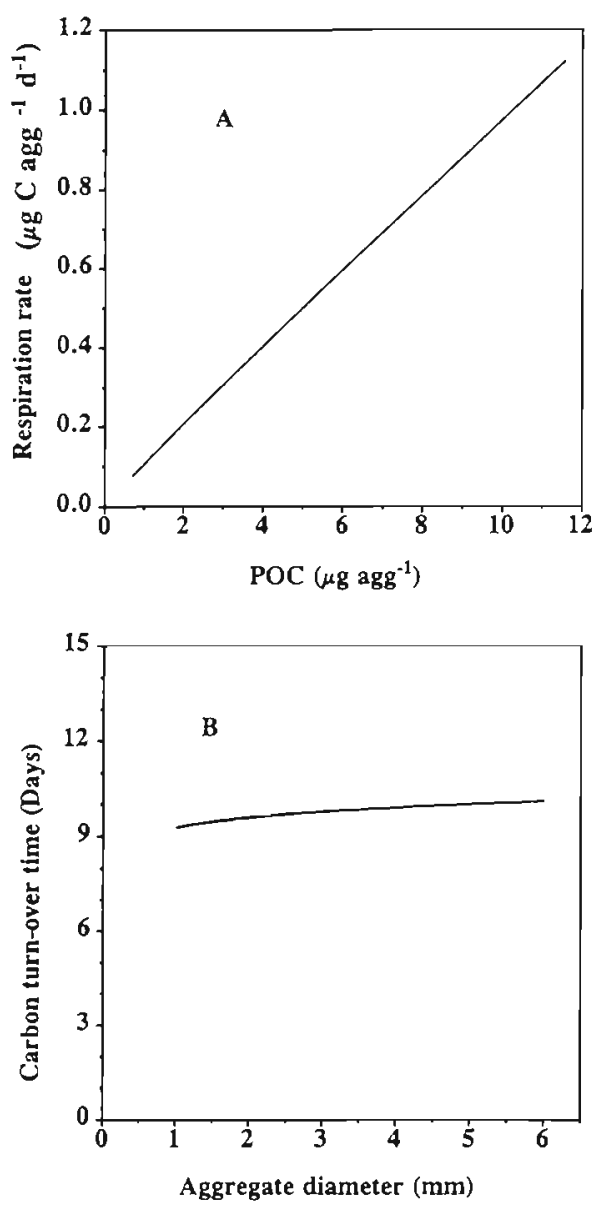

Fig. 6. (A) Respiration rates and (B) carbon turnover time in aggregates of different sizes, calculated using the size specific POC content in aggregates as determined by Alldredge (1998)

(Alldredge 1998) divided by the measured respiration rate as a function of aggregate size from the present study (Fig. 6B). Due to the similar size dependency of respiration and $\mathrm{POC}$ content in marine aggregates, the respiration rates appeared to be proportional to the $\mathrm{POC}$ content, which suggests a tight coupling between POC and respiration in aggregates. As a consequence, the carbon turnover time was rather independent of aggregate size. The turnover time only increased from 9.3 to $10.1 \mathrm{~d}$ for 1 to $6 \mathrm{~mm}$ large aggregates (Fig. 6B). Our estimates of the carbon turnover time of 8 to $9 \mathrm{~d}$ was, thus, close to that predicted in Fig. 6.

If the carbon turnover time is the same for all aggregate sizes as indicated in the present study, the degree of carbon remineralization in aggregates is determined by their residence time in the water column, which also depends on aggregation, scavenging, and disintegration processes. Large aggregates are less common than small ones in surface waters, because they rapidly sink out of the surface waters or disintegrate and produce smaller aggregates due to turbulence (Alldredge et al. 1990, Jackson et ai. 1997). The residence time of aggregates in the water column and the carbon fluxes are further dependent on grazing and defecation by zooplankton (Lampitt et al. 1993, Green \& Dagg 1997) and fishes (Grossart et al. 1998). Since small aggregates are more common in the ocean than larger ones, and small aggregates have much higher respiration rates and $\mathrm{POC}$ content per volume compared to large aggregates, they may contribute more to the carbon remineralization in surface waters than previously presumed.

The flux of POC and PON decreases with increasing depth in the ocean, the highest losses occurring in the upper ocean $(<150 \mathrm{~m})$ followed by a more moderate decrease in the deeper parts of the water column (Knauer et al. 1979, Knauer \& Martin 1981, Lee \& Wakeham 1988 ). In the present study, we have estimated that $80 \%$ of the aggregate carbon would be respired within the aggregate during sedimentation through a water column of $200 \mathrm{~m}$, as these aggregates were relatively slowly sinking. As a consequence of the short turnover time of the aggregate carbon, the respiration in aggregates will become carbon limited and decrease during sedimentation when degradable carbon sources to support respiration can no longer be produced within the aggregates as exudates and hydrolysis products or be scavenged from the surrounding water.

The present study directly demonstrates that sinking aggregates are not only a sink of $\mathrm{CO}_{2}$ fixed in the euphotic zone but they can also be a source of $\mathrm{CO}_{2}$ to the surrounding waters at relatively high light intensities up to $150 \mu \mathrm{E} \mathrm{m}^{-2} \mathrm{~s}^{-1}$ and during sedimentation out of the euphotic zone. The carbon turnover in sinking aggregates due to respiration, only, can be so fast that most of the aggregate carbon will be respired in the surface waters and only a minor fraction of the aggregate carbon will reach the sea floor.

Acknowledgements. Thanks are due to Tony Michaels for providing laboratory space and boating and diving facilities at Wrigleys Institute for Environmental Research, Catalina Island, and to Stephanie Rink and Eric Epping for organizing the cruise. Rudolf Medina, Julie Vogado, Niclas Kummer, and Rebecca Frey are thanked for diving assistance. The microelectrodes were constructed by Gaby Eickert, Anja Eggers, and Vera Hübner at the Max Planck Institute for Marine Microbiology in Bremen. Thomas Richter is thanked for developing software for determination of the surface area of ellipsoids. This study was supported by the Max Planck Society, Germany, and by a postdoctoral fellowship given by the German Science Foundation (DFG) to H.P.G. (Gr 1540/1-1).

\section{LJTERATURE CITED}

Alldredge AL (1979) The chemical composition of macroscopic aggregates in two neretic seas. Limnol Oceanogr $24: 855-866$ 
Alldredge AL (1998) The carbon, nitrogen and mass content of marine snow as a function of aggregate size. Deep-Sea Res I 45:529-541

Alldredge AL, Cohen Y (1987) Can microscale chemical patches persist in the sea? Microelectrode study of marine snow and fecal pellets. Science 235:689-691

Alldredge AL, Gotschalk CC (1990) The relative contribution of marine snow of different origins to biological processes in coastal waters. Cont Shelf Res 10:41-58

Alldredge AL, Silver M (1988) Characteristics, dynamics and significance of marine snow. Prog Oceanogr 20:41-82

Alldredge AL, Cole JJ, Caron DA (1986) Production of heterotrophic bacteria inhabiting macroscopic organic aggregates (marine snow) from surface waters. Limnol Oceanogr 31:68-78

Alldredge AL, Granata TC, Gotschalk C, Dickey TD (1990) The physical strength of marine snow and its implications for particle disaggregation in the ocean. Limnol Oceanogr 35:1415-1428

Amann RI, Binder BJ, Olson RI, Christholm SW, Devereux R, Stahl DA (1990) Combination of $16 \mathrm{~S}$ rRNA-targeted oligonucleotide probes with flow cytometry for analysing mixed microbial populations. Appl Environ Microbiol 56: $1919-1925$

Amann RI, Ludwig W, Schleifer KH (1995) Phylogenetic identification and in situ detection of individual microbial cells without cultivation. Microb Rev 59 (1):143-169

Amon RMW, Benner R (1996) Bacterial utilization of different size classes of dissolved organic matter. Limnol Oceanogr 41:41-51

Azam F, Smith DC, Steward GF, Hagström $\AA$ (1993) Bacteriaorganic matter coupling and its significance for oceanic carbon cycling. Microb Ecol 28:167-179

Broecker WS, Peng TH (1974) Gas exchange rates between air and sea. Tellus 26:21-35

Caron DA, Davis PG, Madin LP, Sieburth JMcN (1982) Heterotrophic bacteria and bacterivorous protozoa in oceanic macroaggregates. Science 218:795-797

Cho BC, Azam F (1988) Major role of bacteria in biogeochemical fluxes in the ocean's interior. Nature 332:441-443

DeLong EF, Franks DG, Alldredge AL (1993) Phylogenetic diversity of aggregate attached vs. free-living marine bacteria assemblages. Limnol Oceanogr 38:924-934

Focht DD, Verstraete W (1997) Biochemical ecology of nitrification and denitrification. Adv Microb Ecol 1:135-214

Fowler SW, Knauer GA (1986) Role of large particles in the transport of elements and organic compounds through the oceanic water column. Prog Oceanogr 16:147-194

Green EP, Dagg MJ (1997) Mesozooplankton associations with medium to large marine snow aggregates in the northern Gulf of Mexico. J Plankton Res 19:435-447

Grossart HP, Simon M (1998) Bacterial colonization and microbial decomposition of limnetic organic aggregates (lake snow). Aquat Microb Ecol 15:127-140

Grossart HP, Berman T, Simon M, Pohlmann K (1998) Occurrence and microbial dynamics of macroscopic organic aggregates (lake snow) in Lake Kinneret, Israel, in fall. Aquat Microb Ecol 14:59-67

Hoppe HG (1993) Use of fluorogenic model substrates for extracellular enzyme activity (EEA) measurements of bacteria. In: Kemp PF, Sherr BF, Sherr EB, Cole JJ (eds) Handbook of methods in aquatic microbial ecology. Lewis Publishers, Boca Raton, p 423-432

Jackson GA, Maffione R, Costello DK, Alldredge AL, Logan BE, Damn HG (1997) Particle size spectra between $1 \mathrm{~mm}$ and $1 \mathrm{~cm}$ at Monterey Bay determined using multiple instruments. Deep-Sea Res 44:1739-1767
Karl DM, Knauer GA, Martin JH (1988) Downward flux of particulate organic matter in the ocean: a particle decomposition paradox. Nature 332:438-441

Knauer GA, Martin JH (1981) Primary production and carbon-nitrogen fluxes in the upper 1,500 $\mathrm{m}$ of the northeast Pacific. Limnol Oceanogr 26:181-186

Knauer GA, Martin JH, Bruland KW (1979) Fluxes of particulate carbon, nitrogen, and phosphorous in the upper water column of the northeast Pacific. Deep-Sea Res 26:97-108

Lampitt RS, Wisher KF, Turley CM, Angel MV (1993) Marine snow studies in the Northeast Atlantic Ocean: distribution, composition and role as a food source for migrating plankton. Mar Biol 116.689-702

Lee C, Wakeham SG (1988) Organic matter in seawater. Chemical oceanography. Academic Press, New York

Logan BE, Wilkinson DB (1990) Fractal geometry of marine snow and other biological aggregates. Limnol Oceanogr 35:130-136

Maas LRM (1994) On the surface area of an ellipsoid and related integrals of elliptic integrals. J Comp Appl Math $51: 237-249$

Mari X, Burd A (1998) Seasonal size spectra of transparent exopolymeric particles (TEP) in a coastal sea and comparison with those predicted using coagulation theory. Mar Ecol Prog Ser 163:63-76

Mari X, Kiørboe T (1996) Abundance, size distribution, and bacterial colonization of transparent exopolymeric particles (TEP) during spring in the Kattegat. J Plankton Res 18:969-986

Parparov AS, Berman T, Grossart HP, Simon M (1998) Metabolic activity associated with lacustrine seston. Aquat Microb Ecol 15:77-87

Ploug $H_{1}$ Jørgensen BB (1999) A net-jet flow system for mass transfer and microsensor studies in sinking aggregates Mar Ecol Prog Ser 176:279-290

Ploug H, Kühl M, Buchholz B, Jørgensen BB (1997) Anoxic aggregates - an ephemeral phenomenon in the ocean Aquat Microb Ecol 13:285-294

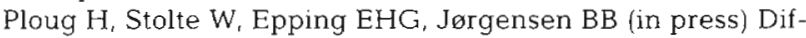
fusive boundary layers, photosynthesis, and respiration of the colony forming plankton algae, Phaeocystis sp. Limnol Oceanogr

Porter KG, Feig YS (1980) The use of DAPI for identifying and counting aquatic microflora. Limnol Oceanogr 25:943-948

Rath J, Ying Wu K, Herndl GJ, DeLong EF (1998) High phylogentic diversity in a marine-snow-associated bacterial assemblage. Mar Ecol Prog Ser 14:261-269

Revsbech NP (1989) An oxygen microelectrode with a guard cathode. Limnol Oceanogr 34:474-478

Revsbech NP, Jørgensen BB, Brix O (1981) Primary production of microalgae in sediments measured by oxygen microprofile, $\mathrm{H}^{14} \mathrm{CO}_{3}{ }^{-}$fixation and oxygen exchange methods. Limnol Oceanogr 26(4):717-730

Schweitzer B (1998) Relation in structure and function of bacterial communities on lake snow. PhD thesis, University of Constance (in German)

Shanks AL, Trent JD (1980) Marine snow: sinking rates and potential role in vertical flux. Deep-Sea Res 27:137-144

Simon M, Alldredge AL, Azam F (1990\} Bacterial dynamics on marine snow. Mar Ecol Prog Ser 65:205-211

Smith DC, Simon M. Alldredge AL, Azam F (1992) Intense hydrolytic activity on marine aggregates and implications for rapid particle dissolution. Nature 359:139-141

Spiegel MR (1968) Mathematical handbook of formulas and tables. Schaum's outline series. McGraw-Hill, Inc, New York

Stoderegger K, Herndl GJ (1998) Production and release of bacterial capsular material and its subsequent utiliz- 
ation by marine bacterioplankton. Limnol Oceanogr 43 : $877-884$

Turley CM, Mackie PJ (1994) Biogeochemical significance of attached and free-living bacteria and the flux of particles in the NE Atlantic Ocean. Mar Ecol Prog Ser 115:191-203 Unanue M, Azúa I. Arrieta JM, Labirua-Iturburu A, Egea L, Iriberri J (1998) Bacterial colonization and ectoenzymatic activity in phytoplankton-derived model particles: cleavage of peptides and uptake of amino acids. Microb Ecol 35:136-146

Editorial responsibility: Tom Fenchel (Contributing Editor), Helsinger, Denmark
Velji MJ, Albright LJ (1986) Microscopic enumeration of attached marine bacteria of seawater, marine sediment, fecal matter, and kelp blade samples following pyrophosphate and ultrasound treatments. Can J Microbiol 32: $121-126$

Weiss P, Schweitzer B, Amann RI, Simon M (1996) Identification in situ and dynamics of bacteria on limnetic organic aggregates (lake snow). Appl Environ Microbiol 62: $1998-2005$

Submitted: October 8, 1998; Accepted: December 22, 1998 Proofs received from author(s): March 29, 1999 